\title{
Learning About Landslide Disaster Mitigation Based on a Role-Playing Method Assisted by the Disaster Education Pocket Book
}

\author{
Erni SUHARINI ${ }^{1}$ \\ Universitas Negeri Semarang, Semarang City \\ INDONESIA
}

\author{
Moh. Nasrul BAHARSYAH ${ }^{2}$ \\ Madrasah Aliyah Riyadlotut Thalabah Sedan \\ INDONESIA
}

\begin{abstract}
${ }^{1}$ Corresponding author: Universitas Negeri Semarang, Faculty of Social Sciences, Geography Department, Sekaran Campus, Semarang, Indonesia, E- mail: erni.suharini [at] mail.unnes.ac.id, ORCID: https://orcid.org/0000-0003-1793-6596 2Madrasah Aliyah Riyadlotut Thalabah Sedan, Rembang Regency, Central Java, Indonesia, E-mail: mohnasrul.baharsyah [at] gmail.com , ORCID: https://orcid.org/0000-0003-1931-1231
\end{abstract}

\begin{abstract}
The importance of understanding disaster issues affecting Indonesia encourages the integration of disaster mitigation into the education system. For instance, the inclusion of disaster mitigation occurs in the subject of geography. However, the implementation of disaster mitigation learning still faces several obstacles. The aim of this study is to describe the implementation of a role-playing learning method assisted by the disaster education pocketbook and to analyze its effectiveness. This research was conducted at SMAN 11 Semarang. The samples of this study were XI IPS 2 as the experimental class and XI IPS 3 as the control class. The variable of this research was the roleplaying learning method assisted by the disaster education pocketbook. The sub-variables include teacher performance, learning outcomes, and students' responses. The study found that implementation of the experimental class obtained teacher performance scores of 89 percent and control classes obtained teacher performance scores of 86 percent. Both scores were very good. The comparison of cognitive learning outcomes showed that disaster mitigation learning with a roleplaying method and assisted by a pocketbook about disaster education was more effective than learning through lectures anddiscussion methods. Responses to a questionnaire showed an average score of 82.7 percent, stating that students were very interested in such learning. The results of this study indicate that disaster mitigation learning must be implemented with a method that involves active student participation and is also complemented by interesting learning materials such as the role-playing method assisted by use of a disaster education pocketbook.
\end{abstract}

\section{Keywords}

Disaster Mitigation; Disaster Education; Pocket Book; Role-Playing Method 
Indonesia is a country located between two continents and two oceans, a meeting between the Indo-Australia and Pacific plates and crossed by the equator. Indonesia does not only have extraordinary natural potential, but also the potential for enormous disasters that can endanger the lives of its citizens (Kurniawan, Sriyanto, \& Syifauddin, 2020; Prasetyo, Bashit, \& Azeriansyah, 2018). One of the regions in Indonesia with a high level of disaster threat is Semarang City, where floods, landslides, drought, and abrasion often occur (Nugraha, Hani'ah, \& Pratiwi, 2017). Of the four disasters, landslides have a very high threat level in Semarang City (Hani'ah, Firdaus, \& Nugraha, 2017; Tjahjono, Suripin, \& Kismartini, 2019; Tjahjono, Suripin, \& Kismartini, 2018). This condition is influenced by the topography of Semarang City consists of both lowlands and highlands with an altitude of approximately 348 meters above the sea level (Susilowardhani, 2014) and dominated by the geological structure of folds and faults (Yulianto, Suripin, \& Purnaweni, 2019).

The importance of understanding disaster problems in Indonesia encourages the integration of disaster mitigation into the education system. As stated by various researchers, disaster education is very effective and crucial in efforts to reduce disaster risk and increase community capacity at responding to disasters (Frankenberg et al., 2013; Hoffmann, \& Blecha, 2020; Pinar, 2017; Rogayan, \& Dollete, 2020; Thayaparan, Malalgoda, Keraminiyage \& Amaratunga, 2014). Disaster education is the foundation of all disaster risk reduction efforts (Kurniawan, Sriyanto, \& Sari, 2019; Sakurai, Bisri, Oda \& Murayama, 2017). For this reason, disaster mitigation is included as part of the curriculum of several subjects in Indonesia.

Formal school's curriculum is not the only way to learn disaster mitigation, even though it still be considered as the most effective way to increase people literate or aware (Shaw, Takeuchi, \& Rouhban, 2009). Learning directly (student-centered learning) makes students aware of disasters that can threaten and to understand their mitigation efforts (Artvinli, 2010a). Furthermore, they can disseminate this knowledge to families and the wider community in their environment (Lamina, 2017). Then, learning and education are the most powerful agent of change in society for improving human capacity (Hanifah et al., 2019). Based on the Regulation of Minister of Education and Culture No. 24 of 2016, disaster mitigation material is included as a subject for geography in the Senior High School level, namely basic competency 3.7 (analyzing the types and management of natural disasters through education, local wisdom, and the use of modern technology). Learning disasters in geography in schools is an effective step in disaster mitigation education, and the learning process method should avoid teacher centered learning (Artvinli, 2010a, 2013). This is because disaster mitigation learning is a form of functional geography knowledge which refers to the application of geographic and related skills for problem-solving efforts in the environment (Kurniawan, \& Trimasukmana, 2020; Mahat et al., 2019). However, the implementation of disaster mitigation learning still experiences several obstacles. 
According to observations and interviews conducted with the geography teacher of class XI, the researcher discovered the teaching materials used at SMA Negeri 11 Semarang are textbooks and worksheets circulating on the market. However, the teaching materials used are not yet complete enough to explain disaster mitigation and adaptation. This is because disaster mitigation material is new content in the geography learning in Senior High School. Erlangga (publisher) has published books used by the students but has not included disaster mitigation material in Basic Competency 3.7. Limited teaching materials also initiate the teachers to overcome these problems through literacy of material from the internet. Many articles describe various types of disasters and the characteristics of disasters. However, these articles have not explained comprehensively the material that is under the basic competencies and existing syllabus. On the other hand, the teaching materials enrichment made have not been setting contextually to improve their knowledge and preparedness of students for the potential disasters of their neighborhood landslides. Besides, according to the students, the teaching materials that have been used still possess too many texts that are difficult to understand. Therefore, we need to supplement teaching materials to clarify student understanding.

In the Indonesia Dictionary, a pocketbook is interpreted as a small book that can be stored in a pocket and easily carried anywhere (Nurjannah, \& Dwi, 2019). Research on the development of pocket-book bulletin media (Asyhari, \& Silvia, 2016) shows that the feasibility of the science bulletin learning media in the form of pocket books is very reasonable with $82 \%$ based on the assessment of final stage material experts. After improvement, design experts say there is $79.4 \%$ eligibility criteria, teacher evaluation at $77.6 \%$ with feasible criteria, and the results of students' responses with a percentage of $80 \%$ with eligibility criteria. Other studies that develop pocketbooks as learning media show effective results including those from (Fahma, Suryani, \& Musadad, 2018; Khulafa, \& Santosa, 2018; Mona, \& Azalea, 2018; Zukmadini, Kasrina, Jumiarni, \& Rochman, 2020).

As a teaching material, a pocketbook has the advantage of being easy to carry so that teachers can supplement teaching material without burdening the students. In addition, it is concise, but it clearly has more interesting content for enthusiastic learning than the thick printed books. Disaster mitigation material needs to be explained briefly and clearly because it is important and applicable for students who live in disaster-prone areas. Therefore, pocketbooks are very suitable to be used as teaching materials for student enrichment (Pudjiastuti, Suparno, Sutisna, \& Ati, 2019).

Then, according to the results of interviews with the students, the researcher obtained some information related to learning models and methods that are usually done in class. Disaster mitigation learning concerning knowledge and preparedness requires an interactive and participatory learning model. However, the implementation of disaster mitigation learning materials at SMA N 11 Semarang has tended to be conventional with the method of lectures and discussions assisted by power point media. According to the research by (Fatonah et al., 2018), the lecture 
learning model has the lowest significance level in increasing disaster knowledge. And then, according to Kurniawan \& Trimasukmana, (2020), students' learning interest is influenced by the way they learn. Therefore, learning geography will be more effective when using appropriate learning media.

One model that can be used is a cooperative model with the role-playing method. The role-playing learning method is a learning method putting students in certain situations outside the classroom, even though at that time, learning takes place in the classroom (Rashid, \& Qaisar, 2017). In disaster learning, role-playing allows students to develop imagination and appreciation when a disaster occurs. (Fatonah et al., 2018) showed that the use of role-playing method significantly influences students' knowledge about earthquake disasters. This is also proven by other researches (Bhattacharjee, 2014; Krisdiana, Irawati, \& Kadarisman, 2018), exemplifying the use of role-playing models that can increase motivation and interaction between teachers and students, as well as between students with other students.

Based on this description, it is necessary to develop learning with interactive and participatory methods supported by teaching materials that complement and are contextualized with the student's home environment. Therefore, this research is entitled "The Landslide Disaster Mitigation Learning Based on Role-Playing Method Assisted by Disaster Education Pocket Book in SMA Negeri 11 Semarang". In this study, learning activities used a role-playing method which was implemented through landslide mitigation drama from the stage of pre-disaster, during disaster, and post-disaster, played by students. Then, to improve students' understanding, interest in learning, and literacy, the researchers compiled a landslide education pocketbook that was adapted to the disaster conditions of the study area.

\section{Methods}

\section{Research Design}

This research is a quasi-experimental study with quantitative data analysis. This study aimed to describe the implementation of a role-playing method of learning and analyze the effectiveness of such a method when assisted by disaster education pocketbook. This study took place at SMA Negeri 11 Semarang. The variables of this study were the role-playing learning method assisted with a disaster education pocketbook. The sub-variables are teacher performance, learning outcomes, and positive student responses. Initial research was carried out to collect preliminary data in the form of an analysis about the need for developing disaster mitigation learning. Subsequent research was conducted to test the methods and learning media developed and then to analyze their effectiveness.

\section{Population and Sample}

The population of this study was students of class XI at SMA Negeri 11 Semarang. The population was chosen because the area around SMA N 11 Semarang (South Semarang Sub-district, Candisari, Gajahmungkur, and Tembalang) is a landslide- 
prone area in Semarang City (Tjahjono, Suripin, \& Kismartini, 2018). The sampling technique used in this study was a probability sampling technique in the form of purposive sampling. The purposive sampling technique was chosen because the researcher wanted to take two classes, namely the control class and the experimental class. There were two samples having almost the same characteristics, taught by the same teacher, at the same time relatively similar learning and possess the same relative learning achievement. Samples taken in this study were students of class XI IPS 2 consisting of 30 students as an experimental class, and class XI IPS 3 that consist of 29 students as a control class.

\section{Data Collection Instruments}

In obtaining data, several methods of data collection are used, namely test, documentation, interview, and questionnaire methods. Each of these methods does not stand alone but rather mutually support and complement each other's findings. The test method is used to measure the cognitive aspects or understanding of students in both experimental and the control class. The test methods used were pre-test and post-test. The instrument used in pre-test and post-test was multiplechoice containing 40 questions. Before used to measure students' cognitive abilities, test instruments needed to be assessed for their validity and reliability. The validity of the test instrument was done by using product-moment correlation, while the reliability of the test instrument was done by using the alpha formula. Besides being tested for validity and reliability, the test instrument was also tested for different test questions and difficulty levels. Then, the documentation method was used to collect student data and school profiles. The interview method was conducted with geography teachers and students in class XI of SMA N 11 Semarang to acquire data on disaster mitigation teaching materials used by students at the school. The questionnaire method was used to determine the feasibility and response of students to learning using the media of the Landslide Disaster Education Pocketbook.

\section{Data Analysis Technique}

Data analysis in this research was performed through several stages. The feasibility analysis was done descriptively through a Likert scale from the results of the feasibility test questionnaire. The assessment of learning effectiveness was enforced by a normality test, a homogeneity test, an $\mathrm{N}$-Gain test, and the average difference test of learning outcomes to determine the difference between the learning outcomes of the experimental class and of the control class. To know students' positive responses, the data obtained from student questionnaire responses after using teaching material was processed.

\section{Findings}

\section{The Overview of Research Locations}

SMA Negeri 11 Semarang is established on November 22, 1985, with Decree No0601/0/1985. This school has a vision of "Creating a School that is Religious, Smart, Skillful, and Environmentally Friendly". In line with its vision, SMA N 11 Semarang holds missions including (1) increasing faith, piety, and noble character, (2) 
enhancing the culture of achievement and quality of graduates, (3) developing science, technology and culture, and then (4) developing an adiwiyata (ideal) school. SMAN 11 Semarang possesses the motto "CEMERLANG", which is an acronym for Cerdas (Smart), Mulia (Noble), Terampil (Skilled), Religius (Religious), and Cinta Lingkungan (Love the Environment)". SMAN 11 Semarang astronomically, the location is at $7^{0} 01$ ' 33 "LS and $110^{\circ} 44^{\prime} 16^{\prime \prime}$ East. SMAN 11 Semarang has an area of $16,560 \mathrm{~m}^{2}$. The access is easy considering its location in the administrative area of Semarang City.

\section{Disaster Education Pocketbook}

A pocketbook is a non-textbook printed lesson, small in size and able to be stored in a pocket so that it is easy to carry anywhere. Furthermore, they are printed in small size to make them more efficient, practical, and easy to use. Pocketbooks also encourage students to learn independently. They are included in the class of printed teaching materials, as there are advantages such as (1) simple and practical form; (2) easy to carry everywhere because of its minimalist shape and can be stored in a pocket, so students can learn whenever and wherever they want; (3) attractive design, which can make students not ashamed to read in public places.

Landslide Disaster Education Pocket Book is integrated with Role-Playing Learning Method; it has a size of $10 \times 12 \mathrm{~cm}$ adjusted to the standard of pocketbook $(10 \times 12$ or $12 \times 14 \mathrm{~cm})$. The author chose the size $10 \times 12 \mathrm{~cm}$ because it matches the average pocket size of the smaller students' uniforms. As such, it has several advantages including: (1) A minimalist size so it is easy to carry. Textbooks from various subjects owned by students are quite a lot so it is remarkably burdensome if added again with other large books. Therefore, the pocketbook is arranged concisely but clearly with a minimalist size so that it does not charge them more; (2) Being equipped with contextual and colorful images. Books equipped with contextual and colorful images attract more students' enthusiasts to read than ones that are only dominated by text; (3) Being integrated with role-playing learning method which according to some studies, has good effectiveness.

Research from (Fatonah et al., 2018), shows that learning using simulation and role-playing methods have good effectiveness for disaster mitigation materials because they involve student participation. However, sometimes the implementation a role-playing method is more complicated as it needs to prepare the theme, problem, as well as a drama script before learning. Guidelines for integrating the role-playing learning in the pocketbook can make it easier for teachers and students to carry out disaster mitigation learning more effectively.

The Landslide Mitigation Pocketbook was prepared by using references from books and articles on landslide mitigation. The content of the pocketbook is integrated and adapted to the conditions of landslide vulnerability in the study area. In so doing, the landslide mitigation pocketbook is contextual so this pocketbook will be very relevant to be taught in the research area. For other school areas, the pocketbook can be prepared with the same concept, with substance or content that 
is adjusted to the potential conditions and vulnerability of the types of disasters that exist in each region.

After being organized properly, the validity of the pocketbook was tested with experts consisting of content experts, instructional media experts, and practitioners. The validity test of the pocketbook is conducted by referring to the book eligibility, which includes: the feasibility of content, the presentation, the linguistic elements, and the graphics. The pocket-book validity test questionnaire was made by breaking down four indicators of its feasibility into 28 assessment items including 13 items of content feasibility assessment, eight items of presentation feasibility assessment, three items of language feasibility assessment, and four items of graphics feasibility assessment. Each item was assessed using a Likert scale with a four-level scale, namely 1 (less), 2 (enough), 3 (good), and 4 (very good). The feasibility criteria for a pocketbook can be seen in Table 1 .

Table 1

The Feasibility Criteria for a Pocketbook

\begin{tabular}{cl}
\hline Percentage Range & Criteria \\
\hline $85 \%<$ score $\leq 100 \%$ & Very Feasible \\
$70 \%<$ score $\leq 85 \%$ & Feasible \\
$50 \%<$ score $\leq 70 \%$ & Quite Feasible \\
$1 \%<$ score $\leq 50 \%$ & Not Feasible \\
\hline
\end{tabular}

After being assessed by experts, results of feasibility analysis for the pocketbook can be seen in Table 2 below.

Table 2

The Feasibility of Landslide Disaster Education Pocketbook being integrated with a RolePlaying Learning Method (Source: Primary data, 2019)

\begin{tabular}{lc}
\hline Aspects Assessed & Score (\%) \\
Content Feasibility & $89.42 \%$. \\
Presentation Feasibility & $88.28 \%$ \\
Linguistic Feasibility & $87.5 \%$ \\
Study Feasibility & $87.5 \%$ \\
\hline
\end{tabular}

Based on overall data calculation, it can be inferred that the Landslide Disaster Education Pocketbook is integrated with a Role-Playing Learning Method, and it is included in the category of "Very Feasible" with an eligibility percentage of $88.62 \%$.

\section{The Implementation of Experimental Class Learning}

The learning process in the experimental class using the role-playing method assisted by the Disaster Education Pocket Book was held three times (six hours) on $13^{\text {th }}, 14^{\text {th }}$, and $20^{\text {th }}$ May 2019. Learning opened with a self-introduction to familiarize the teacher (researcher) with the students. The researcher then explained the learning activities to be delivered using a role-playing method which was assisted by use of the disaster education pocketbook. Before starting class, researchers asked about student readiness to participate in learning. When the students were ready, 
the researcher conducted a pre-test to find out students' knowledge about natural disaster mitigation and adaptation material before learning was carried out.

After conducting the pre-test, the teacher conveyed the stimulation of disaster mitigation material by describing some actual problems of disaster events in Indonesia, particularly in the City of Semarang. From the presentation, students expressed their opinions about the definition of disaster, its causes, and disaster types. The teacher then answered all questions and provided conclusions about the meaning, causes, and types of disasters, as well as presenting an understanding about the importance of disaster education for students in schools.

In this first meeting, the researcher carried out the first to third steps of learning, namely warming up the group atmosphere, participant selection, setting the place, and preparing students as observers. For the first step, the teacher encouraged students to jointly identify and explain the problems of landslides that often occur in villages and sub-districts around SMA N 11 Semarang. After students contextually understood the problem of landslides, the teacher prepared an explanation of the role-play learning to be carried out. Then, the teacher distributed the Landslide Disaster Education Pocketbook.

The teacher and the students paid attention and analyzed the drama scenario. After the students understood the characteristics of each role, the second step was to take participant selection, where the teacher divided the roles for the students. Then, the third step was the setting where the teacher explained the role sessions and reaffirmed the students' roles in the drama. Then, the last was the preparation of students as observers because there were several sessions, and all students were involved in drama. Every student who did not take a role was asked to observe ones who played the drama.

In the second meeting, the fifth to ninth steps occurred, such as discussion and evaluation, sharing and generalization, learning by checking students' readiness, pray together, then motivate students. Before characterization, the teacher gave a moment so that all students prepared and paid close attention. When the students were ready, the teacher let the drama play.

This drama is entitled "Let's Become the Generation of SIGAB (Prepared for Disaster Preparedness"), consisting of Drama 1 "Prediction of Disaster 2019", 2nd Drama "Avalanche Event in Candisari", 3rd Drama "Symptoms, Types and Causes of Landslides, and Drama 4 "Characteristics of Landslide Prone Areas and Landslide Mitigation Efforts". At the end of each session, the teacher conducted discussions and evaluations to check students' understanding before continuing to the next drama. After that, the final stage was done, namely sharing and generalizing experiences that connect situations that are portrayed with life in the surrounding environment and problems that may arise. This discussion activity becomes important in learning so students can know various environmental concepts from peers (Ichsan et al., 2019; Ilyasa et al., 2020)

After learning, teachers and students reflected on learning activities and its results Reflection held at the end of the meeting, then the teacher held a post-test to determine student learning outcomes as the learning has been implemented. 
Afterwards, the teacher asked students to fill out a questionnaire to find out how students' interests and responses.

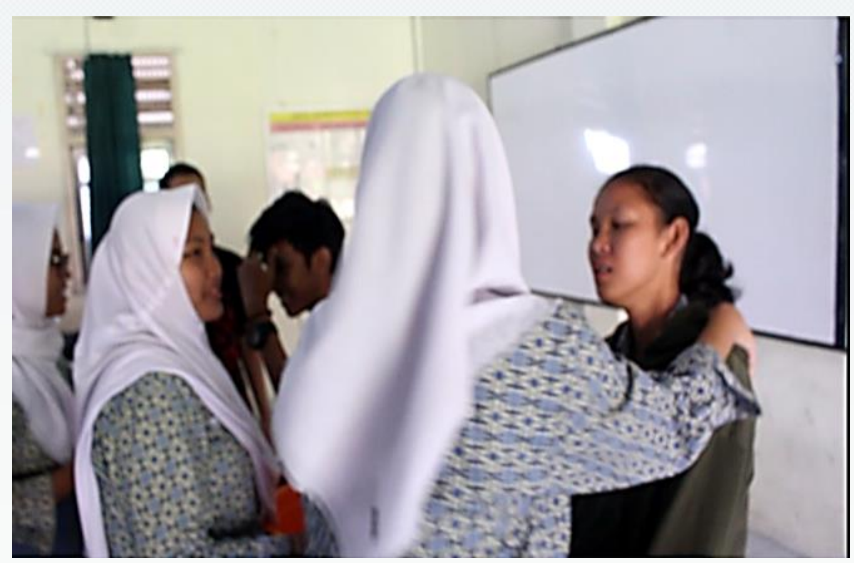

Figure 1. Experimental Classroom Learning Situation (source: personal documentation)

The implementation of learning in the experimental class was carried out by the researcher and assessed by the geography teacher and one fellow researcher. The assessment was carried out for 3 meetings. Assessment of the implementation of learning was held by using teacher performance appraisal. Teacher performance was assessed through observation using observation instrument sheets consisting of pre-learning indicators, opening learning, mastery of the material, approach or learning strategies, utilization of learning resources or learning media, learning that stimulates student involvement, assessment of learning processes and outcomes, use of language, and close learning. The indicators are then broken down into 26 items of assessment and assessed with 4 scoring scales from 1-4. The criteria for evaluating teacher performance can be seen in Table 3 below.

Table 3

The Criteria for Evaluating Teacher Performance

\begin{tabular}{cl}
\hline Percentage Range & Criteria \\
\hline $85 \%<$ score $\leq 100 \%$ & Very Good \\
$70 \%<$ score $\leq 85 \%$ & Good \\
$50 \%<$ score $\leq 70 \%$ & Enough \\
$1 \%<$ score $\leq 50 \%$ & Bad \\
\hline
\end{tabular}

After observation, the teacher's performance scores in the experimental class can be seen in Table 4 .

Table 4

Teacher Performance Evaluation Class Experiment (Source: Primary data, 2019)

\begin{tabular}{ccccccc}
\hline No. & Experiment Class & \multicolumn{2}{c}{ Score Percentage (\%) } & Average & Criteria \\
1. & Observer 1 & $\mathbf{1}$ & $\mathbf{2}$ & $\mathbf{3}$ & & \\
2. & 85,6 & 89,4 & 90,4 & $88,5 \%$ & Very Good \\
& Observer 2 & 87,5 & 90,4 & 92,3 & $90,1 \%$ & Very Good \\
Average & & & & $89,3 \%$ & Very Good \\
\hline
\end{tabular}


Based on observations of teacher performance conducted during three meetings by the two observers, it is known that the average performance of the teacher is included in the excellent category with an average of $89.3 \%$.

\section{The Implementation of Control Class Learning}

Learning in the control class applied discussion learning methods and lectures assisted by power point media. The class used as the control class is class XI IPS 3 with a total of 30 students. Learning took place in three meetings (six hours) starting on 7, 13, and 14 May 2019. Every single learning process was opened with selfintroduction to familiarize the implementing teacher (researcher) with students. The researcher then explained the learning activities that would be conveyed using the discussion method. Before starting, researchers asked students' readiness to participate in learning. After the students were ready, the researcher conducted a pre-test to find out the extent of students' knowledge about natural disaster mitigation and adaptation material prior to learning.

Afterward, the teacher conveyed the stimulation of disaster mitigation material by describing some of the actual problems of disaster events in Indonesia, especially in Semarang. From the simulation, the students raised questions and opinions about what a disaster is, the causes of disasters, and the types of disasters. The teacher answered all of them, concludes, and gave an explanation of the meaning, causes, types, and disaster management cycles. The teacher also performed an understanding of the importance of disaster education for students in schools. After providing learning stimuli for students, the teacher asked them to gather information from disaster-related websites about the types and characteristics of disasters around the school.

The second meeting was carried out in the form of discussion activities. Before starting, the teacher checked students' readiness, provided student motivation, and did apperception, as well as question and answer about previous material. The teacher divided students into several groups to discuss data on the results of literacy previously assigned. During the discussion, the teacher was monitoring the discussion. The results of the discussion were then written in a notebook and the teacher guided students to present them.

Each group presented their discussion results in front of the class. Other groups responded by giving questions, suggestions or input and making small notes to compare with the results of their understanding. The teacher evaluated students' knowledge and understanding through question and answer, as well as giving them the opportunity to listen and speak up for information exchange. The knowledge that has been understood during learning should be implemented in the form of environmental preservation behavior (Ichsan et al., 2020)

After exposure, students reviewed and concluded the results of the discussion in groups. The teacher gave reinforcement to motivate the group that had presented their results and added an explanation to the new and different material in each group. When the discussion activity was over, the teacher facilitated students in finding conclusions about the types and characteristics of disasters around the school such as symptoms of landslides, their types, and efforts to mitigate. They also 
reflected on learning activities and its results that have been carried out. Reflection was held at the end of the meeting, as then the teacher performed a post-test to determine student learning outcomes.

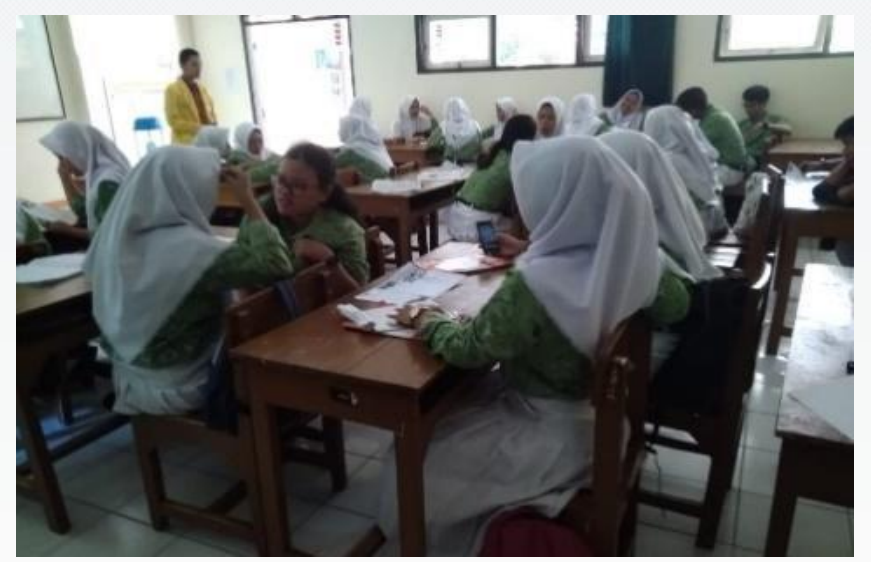

Figure 2. Control Class Learning Situation (source: personal documentation)

The implementation of learning in the control class was held by the researcher and assessed by the geography teacher and one fellow researcher. Assessment of the implementation of learning using lecture learning methods assisted by power point was done for three meetings. Teacher performance appraisal in the control class was performed using the same methods and indicators as the teacher performance appraisal in the experimental class. Teacher performance data can be seen in Table 5.

Table 5

Recapitulation of Teacher Performance Evaluation in Control Class (Source: Primary data, 2019)

\begin{tabular}{ccccccc} 
No. & Control Class & \multicolumn{9}{c}{ Score Percentage (\%) } & Average & Criteria \\
& & $\mathbf{1}$ & $\mathbf{2}$ & $\mathbf{3}$ & & \\
1. & Observer 1 & 83,7 & 84,6 & 88,5 & $85,6 \%$ & Very Good \\
2. & Observer 2 & 85,6 & 87,5 & 88,5 & $87,2 \%$ & Very Good \\
& Average & & & & $86,4 \%$ & Very Good \\
\hline
\end{tabular}

Based on observations of teacher performance conducted during three meetings by the two observers, it is known that the average of control class teacher performance is included in the excellent category, with an average of $86.4 \%$.

\section{The Comparison of Experimental Class and Control Class Learning Outcomes}

Assessment of students' cognitive learning outcomes was done using data collection techniques in the form of tests. The assessment was performed at the end of the meeting by giving 40 multiple choice questions covering all indicators of competency achievement. Test results were analyzed quantitatively with a statistical formula. Statistical tests carried out included the normality test, homogeneity test, t-test, and $\mathrm{N}$-Gain test. t-test is used to test the differences in learning outcomes between the experimental class and the control class. While the 
$N$-Gain test is to determine the increase in learning outcomes in the experimental and control classes obtained from the calculation of the pre-test and post-test.

The average pre-test score of the experimental class students before learning was 73.5. Out of 30 students, there are six who have not yet completed the minimum completeness criteria (KKM). The minimum completeness criteria for geography subject for both experimental and control class is 70. After participating in the learning of landslide disaster mitigation using role-play learning with a pocket-book method, the average score increased to 84.6 with the lowest score of 70 , and the highest score of 93. The average score of the control class pre-test was 72.2. 9 out of 29 students have not yet reached KKM in the pre-test. After participating in landslide disaster mitigation learning using lecture and discussion methods, the average cognitive learning outcomes of control class students increased to 78.3. The lowest score is 63, and the highest score is 93. In the control class, there are 2 out of 29 students whose post-test scores have not yet reached the KKM. After the t-test, the results can be seen in Table 6 below.

Table 6

The Result of t-test Analysis (Source: Primary data, 2019)

\begin{tabular}{rlrcccl}
\hline Data & \multicolumn{1}{c}{ Class } & $\mathbf{X}$ & $\mathbf{D k}$ & $\begin{array}{c}\text { Sig (2- } \\
\text { tailed) }\end{array}$ & $\boldsymbol{\alpha}$ & \multicolumn{1}{c}{ Criteria } \\
Pretest & Experimental & 73,5 & 57 & 0,396 & 0,05 & $\begin{array}{l}\text { The two classes have } \\
\text { relatively similar } \\
\text { effectiveness differences }\end{array}$ \\
Control & 72,2 & & & & $\begin{array}{l}\text { The two classes have } \\
\text { Pifferent effectiveness }\end{array}$ \\
\hline
\end{tabular}

Table 6 shows that there are significant differences in post-test results between the experimental and the control class. The experimental class, in which the roleplaying learning method assisted by disaster education pocketbook was applied, has higher effectiveness. Then, based on the results of the N-Gain test, it can be seen that the increase in learning outcomes between the experimental classes is higher than the control class. N-Gain test results can be seen in Table 7 below.

Table 7

The Result of N-Gain Test Analysis (Source: Primary data processed, 2019)

\begin{tabular}{cccc}
\hline \multicolumn{2}{c}{ Experimental Class } & \multicolumn{2}{c}{ Control Class } \\
X (category) & $Y$ (total students) & X (category) & Y (total students) \\
Low & 7 & Low & 22 \\
Moderate & 23 & Moderate & 7 \\
Total & 30 & Total & 29 \\
\hline
\end{tabular}

Based on Table 7, there is an increase in learning outcomes of the experimental class using the N-Gain formula, as 23 students achieved the criteria of "moderate", while seven students are classified in the "low" category. In classical averages, the entire experimental class is classified as a "medium" criterion with an average $\mathrm{N}$ Gain score of 0.43 . This is different from the control class. Only seven students reached the criteria of "medium", as the rest (23 students) are categorized in the "low" category. In classical average, the control class students are classified as "low" criteria with an average $\mathrm{N}$-Gain score of 0.22 . This indicates that the learning environment for the future still requires a lot of learning innovation (Byers, Imms, 
\& Hartnell-Young, 2018). Comparison of increasing learning outcomes and completeness score against the minimum completeness criteria between the experimental class and the control class shows that the learning of landslide disaster mitigation with the method role-playing assisted by the disaster education pocketbook is more effective than the lecture and discussion method. In the roleplaying method, all students participate in playing the drama.

So, in learning through role-play, students would play a drama with the theme of landslide. In this study, the drama's setting is in the research area, which is a landslide-prone area. The plot of the drama tells how the disaster event and disaster mitigation from pre-disaster, during the disaster, and after the disaster. To play the drama of the landslide disaster, the students share the role (character). Some students play the role as victims, while others play a role as the community, the Regional Disaster Management Agency team (BPBD), the chairman of the Meteorology, Climatology and Geophysics Agency (BMKG), and the National Disaster Management Agency (BNPB), and medical staff. Students would do the story under the characters being played and would carry out the tasks of each character. This learning method allows students to be directly involved in the atmosphere of a disaster incident that seems to actually occur. So, students will know the steps of disaster mitigation in depth because they play it, and they will also be more enthusiastic because all are actively involved in drama.

\section{Students' Responses after Learning Using Disaster Education Pocket-Book Integrated with Role-Playing}

Interests and responses of students to learning are known for distributing questionnaires. The questionnaire was filled in accordance with the experience of the students when learning disaster mitigation with a role-play method assisted by the disaster education pocketbook. The results of the recapitulation questionnaire can be seen in Table 8 below.

Table 8

The Recapitulation of Response (Source: Primary data, 2019)

\begin{tabular}{llcl}
\hline Interval & Criteria & Frequency & (\%) \\
\hline $81.25-100 \%$ & Very Interested & 10 & 33.3 \\
$62.51-81.24 \%$ & Interested & 20 & 66.6 \\
$43.75-62.50 \%$ & Quite Interested & - & 0 \\
$25-43.74 \%$ & Less Interested & - & 0 \\
Average & & & $82.7 \%$ \\
\hline
\end{tabular}

Analysis of questionnaire data filled out by students shows that $33.3 \%$ of students are "very interested" and $66.6 \%$ of students are "interested" in learning disaster mitigation with a role-play method assisted by use of the disaster education pocketbook. The mean score is $82.7 \%$ so it can be concluded that the implementation of learning gets a positive response from students.

\section{Discussion}

Based on the comparison of learning outcomes and completeness scores against minimum completeness criteria, it shows that learning of landslide disaster mitigation with role-playing method assisted by disaster education pocketbook is 
more effective than learning by lecture and discussion. The role-playing method will increase student knowledge because it facilitates students to learn from their mistakes. In this method, students will learn new things while exchanging dialogues with each other to represent certain characters (Rashid, \& Qaisar, 2017). In addition, the roles they play will also encourage students to be actively involved and provide opportunities for them to connect between theories learned in the classroom and those practiced (Ma, 2020). As in the material of landslide mitigation, students will be involved in playing roles to understand various parties or stakeholders when a landslide occurs so that they will get new knowledge about landslide mitigation from other friends through dialogues.

The role-playing method is a form of experiential learning presupposing that knowledge is gained through concrete experience (doing) (Zamboanga et al., 2016), reflective observation (thinking back to experience) (Wijaya, Rahmat, \& Kokom, 2018), abstract conceptualization (forming observed theories), and active experiments (testing new theories) (McCarthy, 2010). Therefore, this method succeeded in increasing students' active responses and student learning outcomes. This is also in line with the learning experience cone of Edgar Dale, stating children's learning experiences start from the most concrete things to the things that are considered the most abstract (Artvinli, 2010b). The experience classification is better known as the cone of experience, which consists of 12 types of media classifications and the teaching methods used. The twelve classifications starting from the most abstract are reading, listening, and seeing, to the highest level, namely doing drama presentations, simulating real experiences, and doing real things (Guthrie et al., 2018)

Based on the Dale cone, a theory can be drawn, pointing out students who only learn verbally will automatically have a different understanding from students who learn through direct experience. The more concrete the way of learning of a student, the more experience will be gained (Fajriah, \& Churiyah, 2015). So, learning based on experience and reality or from credible simulations that are active and based of experiential learning will be more effective and easier in transferring knowledge than passive learning, only filled with sitting, listening, watching, and reading (Matijević, 2012).

This is in accordance with the results of this study, where the learning of landslide disaster mitigation with the role-playing method assisted by the disaster education pocketbook is more effective than learning with the lecture and discussion. Based on the Dale learning experience cone (Jackson, 2016), the discussion method only gives students a learning experience of 70\%. Meanwhile, the role-playing method provides students with a learning experience of $90 \%$ (Davis, \& Summers, 2015). In the discussion method, students only learn the material and then exchange opinions with their friends, while in the role-playing method, they are directly involved in realistic experiences in which there is not only a process of exchanging information, 
but also involved playing roles to portray various parties or stakeholders when a landslide disaster occurs.

This result is consistent with the statement of (Moreno-Guerrero et al., 2020), showing that learning with a role-playing method can foster positive attitudes high interest, motivation, interaction with the substance of the lesson, autonomy, collaboration between students, attention, self-regulation and creativity, and make students the center in the learning process. Learning with a role-playing method can increase students' motivation in learning. This is also in line with the opinion of Krebt (2017) and Castro (2019), that learning by using role-playing can escalate students' motivation because it is fun and can foster communication cooperation between them.

The high effectiveness of learning using the role-playing method is the implication of the activeness and real action of students in the learning process. Through the role-playing method, students' critical thinking skills will increase (Sofyan, Buaja, \& Rahman, 2018) Besides, with that method, the ability of problemsolving in students will also upgrade (Ma, 2020). This is because the role-playing method will help students to get involved in acting as real situations. It provides tools for students to explore their feelings, gain insights from their attitudes, develop their self-confidence, develop problem-solving abilities, and eliminate their shame through interactions with others (Mudofir, Maftuh, Supriyanto, \& Purwaningsih., 2019; Rashid, \& Qaisar, 2017). This also causes students to be very interested in learning to role-play.

When playing a role, students are compelled to reflect on the knowledge possessed and act according to that knowledge. Thus, it will provide an opportunity for students to reflect on their knowledge of the subject matter to make good and effective decisions, pushing them to stimulate critical thinking skills (Bhattacharjee, 2014; King, 2010). This method will advance the creativity of students because they are required to act under what is desired as if the events in the role-playing scenario were truly experienced. It will also reflect on how much students can understand and absorb the subject matter delivered (Krisdiana, Irawati, \& Kadarisman, 2018).

Then, the experiences played by students, they can appreciate more about disaster incidents, as students are stimulated to have sensitivity and concern for the environment and surrounding communities. This is in line with the statement of (Kilgour, Reynaud, Northcote, \& Shields., 2015), stating that the role-playing method provides guidance to students towards understanding their behaviors and roles in social interactions, developing empathy with others, and finding better problemsolving. This condition is due to the role-playing method which involves actors and observers, becoming a miniature of the real incident so that strong analysis and feelings emerge (Kilgour, Reynaud, Northcote, \& Shields. 2015; Zamboanga et al., 2016).

The success of the role-playing method in this research is supported by the existence of a pocketbook utilized as teaching material which is very important for 
teachers and students. As stated by Perbowo \& Anjarwati (2017) teaching materials can help teachers and students carry out the learning process well in class. Good teaching materials must meet certain qualifications according to those specified by the curriculum. In addition, because it is intended for students, the production of teaching materials must also be designed systematically and attractively to facilitate student understanding.

In this study, the role-playing method is collaborated with a pocketbook, functioning as non-textbook to enrich student literacy. The use of pocketbook certainly contributes to advance the effectiveness of learning about landslide disaster mitigation. Guidelines for integrating learning methods of role-playing in a pocketbook can make it easier for teachers and students to do disaster mitigation learning more effectively.

The effectiveness of using pocketbooks in disaster learning is due to various advantages of a pocketbook. According to (Pudjiastuti, Suparno, Sutisna, \& Ati. 2019), pocketbook has a character to stimulate students' enthusiasm in learning and show their interest during the learning process. Students become more active and pay attention to the teacher who explains. Pocketbooks also have materials that are more easily accepted and understood by students because they are simple. The advantages of pocketbooks are also they contribute to improving student learning outcomes and increasing students' positive responses in learning to mitigate landslides.

Disaster mitigation is an effort to prevent the occurrence of a disaster or minimize its impact (Suharini, Meliana, Sanjoto, \& Kurniawan. 2020). Innovation in the form of a merging of role-play methods assisted by using a pocketbook about landslide disaster mitigation learning is an important finding to improve the quality of disaster mitigation in schools. In an effort for Disaster Risk Reduction (DRR), one of the most important things is strengthening community capacity in the education sector. According to Petal, the essence of disaster risk reduction education is the axiom that disaster cannot be avoided (Shaw, Takeuchi, \& Rouhban, 2009). Knowledge management is very important because students are subject to disaster risk. According to (Pathirage, Seneviratne, Amaratunga, \& Haigh. 2012), knowledge management can generally be interpreted as a strategy to collect, store, and retrieve knowledge systematically, and then distribute the results to those who need in a timely manner. In other words, knowledge management is about providing the right knowledge, in the right place, at the right time.

Knowledge management can be done with disaster education. Disaster education can be a step toward sustainable disaster risk reduction. Education for Sustainable Disaster Risk Reduction (ESDRR) is an educational concept that carries the mission of forming wise human behavior in responding to and treating its environment prone to disasters. It's all based on normal ethical values to create a harmonious life order at present, while preserving its sustainability for the benefit of future generations (Suharini, Setyowati, \& Kurniawan, 2017). Knowledge of disaster 
management strategies, together with good practices and lessons, can undoubtedly support this effort through well-informed mitigation and preparedness measures (Pathirage, Seneviratne, Amaratunga, \& Haigh. 2012).

\section{Conclusion}

Comparison of learning outcomes and completeness scores against the minimum completeness criteria, shows that learning of landslide disaster mitigation with the role-playing method assisted by a disaster education pocketbook is more effective than learning by lecturing and discussion. Disaster mitigation education is an effort to transfer knowledge, attitudes, and skills to the community to reduce the threat and vulnerability of disasters and increase capacity so as to reduce the risk of disasters in society. Innovation of the role-playing method assisted by a pocketbook in disaster mitigation learning is an important finding to be implemented because it can improve the quality of disaster education in the community early on. The results of this study indicate that disaster mitigation learning must be enforced with a method that can involve active student participation and be complemented with interesting learning materials for them such as the role-playing method with a disaster education pocketbook. This is because disaster learning has enormous importance for students so that ideal learning methods and teaching materials are needed to escalate both students' knowledge and skills in dealing with disasters

In its implementation, disaster mitigation learning must also be contextual under the conditions of potential disasters around the student's residence location, as it will have a greater and more effective impact in the teaching process. Role-playing learning method and disaster education pocketbooks can be implemented for other schools. However, they must be set according to the potential disaster conditions around the school concerned. Students must also be taught about mitigation for other types of disasters because disasters can occur anytime and anywhere, while humans are mobile and may enter disaster-prone areas.

\section{Acknowledgement}

This work was supported by the Department of Geography, Faculty of Social Sciences, Universitas Negeri Semarang, Indonesia.

\section{References}

Artvinli, E. (2010a). Teaching styles of geography teachers. Electronic Journal of Social Sciences, (9), 33, pp. 387-408. Retrieved from https://dergipark.org.tr/tr/pub/ esosder/issue/6147/82543

Artvinli, E. (2010b). Configuring of geography lessons: design of a lesson based on action research, Marmara Geographical Review, (21), 184-218. Retrieved from https://dergipark.org.tr/tr/download/article-file/3204

Artvinli, E. (2013). Configuring of geography lessons: design of a lesson based on action research. Mamara Geographical Review, 21, 184-218. 
Asyhari, A., \& Silvia, H. (2016). Pengembangan media pembelajaran berupa buletin dalam bentuk buku saku untuk pembelajran IPA terpadu. Jurnal Ilmiah Pendidikan Fisika AlBiruni, 5(1), 1-13.

Bhattacharjee, S. (2014). Effectiveness of role-playing as a pedagogical approach in construction education. 50th ASC Annual International Conference Proceedings. Westin, Washinton DC: The Associated Schools of Construction.

Byers, T., Imms, W., \& Hartnell-Young, E. (2018). Comparative analysis of the impact of traditional versus innovative learning environment on student attitudes and learning outcomes. Studies in Educational Evaluation, 58(4), 167-177.

Castro, L. (2019). Strengthening english language teaching in rural schools through the roleplaying: teachers motivations. International Journal of Educational Methodology, 5(2), 289-303.

Davis, B., \& Summers, M. (2015). Applying dale's cone of experience to increase learning and retention: A study of student learning in a foundational leadership course. QScience Proceedings, 2(4), 6-13.

Fahma, N., Suryani N., \& Musadad, A. A. (2018). The development of pocketbook as an accounting teaching material. Advances in Social Science, Education and Humanities Research, 165(9), 99-103.

Fajriah, N., \& Churiyah, M. (2015). Utilizing instructional media for teaching infrastructure administration. Jurnal Teknologi Informasi \& Komunikasi Dalam Pendidikan, 2(2), 187-200.

Fatonah, A., Safriani E. W., Wiwin, H., Rose, A., \& Fajariah, A. (2018). Peningkatan pengetahuan bencana menggunakan buku panduan pembelajaran kebencanaan di kabupaten klaten. Seminar Nasional Geografi Dan Pembangunan Berkelanjutan, Jakarta, Universitas Indonesia.

Frankenberg, E., Sikoki, B., Sumantri, C., Suriastini, W., \& Thomas, D. (2013). Education, vulnerability, and resilience after a natural disaster. Ecology and Society, 18(2). 16-26

Guthrie, D. M., Davidson, J. G. S., Williams, N., Campos, J., Hunter, K., Mick, P., ... Wittich, W. (2018). Combined impairments in vision, hearing and cognition are associated with greater levels of functional and communication difficulties than cognitive impairment alone: Analysis of interRAI data for home care and long-term care recipients in Ontario. PLOS ONE, 13(2), 1-27.

Hani'ah, Firdaus, H. S., \& Nugraha, A. L. (2017). Analysis of environmental vulnerability in the landslide areas (case study: semarang regency). IOP Conference Series: Earth and Environmental Science, 98(1).

Hanifah, M., Mohmadisa, H., Yazid, S., Nasir, N., \& Balkhis, N. S. (2019). Professional and pedagogical competencies of geography teachers in Malaysia. Review of International Geographical Education Online, 9(2), 304-318.

Hoffmann, R., \& Blecha, D. (2020). Education and disaster vulnerability in Southeast Asia: Evidence and policy implications. Sustainability (Switzerland), 12(4), 1-17.

Ichsan, I. Z., Rahmayanti, H., Purwanto, A., Sigit, D. V., Kurniawan, E., Dewi, A. K., ... Marhento, G. (2020). Covid-19 dan e-learning: perubahan strategi pembelajaran sains dan lingkungan di SMP. Journal Inovasi Pembelajaran. 6, 50-61.

Ichsan, I. Z., Sigit, D. V., Miarsyah, M., Ali, A., Arif, W. P., \& Prayitno, T. A. (2019). HOTS-AEP: Higher order thinking skills from elementary to master students in environmental learning. European Journal of Educational Research, 8(4), 935-942. 
Ilyasa, F., Rahmayanti, H., Muzani, M., Ichsan, I. Z., \& Suhono, S. (2020). Environmental education for prevent disaster: a survey of students knowledge in beginning new normal of COVID-19. International Journal on Advanced Science, Education, and Religion, 3(2), 1-8.

Jackson, J. (2016). Myths of active learning: edgar dale and the cone of experience. HAPS Educator, 20(2), 51-53.

Khulafa, F. N., \& Santosa, P. (2018). The developmet of pocket book as learning media to make batik jumput in multicultural arts and scraf subject. Asia Pasific Journal of Contemporary Education and Communication Technology, 4(1), 51-57.

Kilgour, P. W., Reynaud, D., Northcote, M. T., \& Shields, M. (2015). Role-playing as a tool to facilitate learning, self reflection and social awareness in teacher education. International Journal of Innovative Interdisciplinary Research, 2(2), 8-20.

King, K. P. (2010). the King'S carpet: Drama play in teacher education. Online Submission, $3(1), 39-60$.

Krebt, D. M. (2017). The effectiveness of role play techniques in teaching speaking for EFL College Students. Journal of Language Teaching and Research, 8(5), 863.

Krisdiana, B. P., Irawati, E., \& Kadarisman, A. E. (2018). The effectiveness of role-play integrated with word cards on students' speaking skill for communication. Jurnal Pendidikan Humaniora, 6(2), 78-84.

Kurniawan, E., Sriyanto, \& Sari, S. N. (2019). Development strategy of cadres students on school based environmental and disaster awareness. IOP Conference Series: Earth and Environmental Science, 243(1).

Kurniawan, Edi, Sriyanto, S., \& Syifauddin, M. (2020). The academic community capacity of The Universitas Negeri Semarang (UNNES) in dealing with natural disasters. 1st International Conference on Environment and Sustainability Issues (ICESI). Semarang City: Universitas Negeri Semarang.

Kurniawan, Edi, \& Trimasukmana, D. J. (2020). Korean drama as geography's audio-visual learning media of disaster mitigation. Universal Journal of Educational Research, 8(5), 2184-2190.

Lamina, O. G. (2017). School-community cooperation in natural disaster education and preparedness in Barangay Dolores, Taytay, Rizal, Philippines. Higher Education Forum, 129-144.

Ma, Z. F. (2020). Role play as a teaching method to improve student learning experience of a bachelor degree programme in a transnational context: an action research study. Compass: Journal of Learning and Teaching, 13(1), 1-10.

Mahat, H., Hashim, M., Saleh, Y., Nayan, N., \& Norkhaidi, S. B. (2019). Factor analysis on energy saving knowledge among primary school students in Malaysia : A case study in Batang Padang district, Perak. Kasetsart Journal of Social Sciences, 40, 448-453.

Matijević, M. (2012). The new learning environment and learner needs this century. Procedia - Social and Behavioral Sciences, 46, 3290-3295.

McCarthy, M. (2010). Experiential learning theory: from theory to practice. Journal of Business \& Economics Research (JBER), 8(5), 131-140.

Mona, D., \& Azalea, F. W. (2018). Leaflet and pocketbook as an education tool to change level of dental health knowledge. Bali Medical Journal, 7(3), 760-763. 
Moreno-Guerrero, A. J., Rodríguez-Jiménez, C., Gómez-García, G., \& Navas-Parejo, M. R. (2020). Educational innovation in higher education: Use of role playing and educational video in future teachers' training. Sustainability (Switzerland), 12(6).

Mudofir, I., Maftuh, M. F., Supriyanto, M., \& Purwaningsih, H. (2019). Improving fluency skill in english speaking through role playing learning strategy at english study program, administration business department, state polytechnic of madiun. International Journal of Multicultural and Multireligious Understanding, 6(4), 52.

Nugraha, A. L., Hani'Ah, \& Pratiwi, R. D. (2017). Assessment of multi hazards in Semarang City. AIP Conference Proceedings, 1857, 1-9.

Nurjannah, \& Dwi, D. F. (2019). The Implementation of pocket book as development of learning media to improve students' motivation. Middle-East Journal of Scientific Research, 27(6), 508-510.

Pathirage, C., Seneviratne, K., Amaratunga, D., \& Haigh, R. (2012). Managing disaster knowledge: Identification of knowledge factors and challenges. International Journal of Disaster Resilience in the Built Environment, 3(3), 237-252.

Perbowo, K. S., \& Anjarwati, R. (2017). Analysis of students' learning obstacles on learning invers function material. Infinity Journal, 6(2), 169.

Pinar, A. (2017). What is secondary school students' awareness on disasters? a case study. Review of International Geographical Education Online, 7(3), 315-331.

Prasetyo, Y., Bashit, N., \& Azeriansyah, R. (2018). Analysis of landslide disaster impact identification using unmanned aerial vehicle (UAV) and geographic information system (GIS) (case study: Ngesrep Sub District, Semarang City). MATEC Web of Conferences, 159, 0-5.

Pudjiastuti, S. R., Suparno, Sutisna, M., \& Ati, H. M. (2019). The development of pocket book learning media based on mind mapping, dynamic material application of indonesian democracy in senior high school. Advances in Social Science, Education and Humanities Research, 418, 313-320.

Rashid, S., \& Qaisar, S. (2017). Role Play: a productive teaching strategy to promote critical thinking. Bulletin of Education and Research, 39(2), 197-213.

Rogayan, D. V., \& Dollete, L. F. (2020). Disaster awareness and preparedness of barrio community in Zambales, Philippines: Creating a baseline for curricular integration and extension program. Review of International Geographical Education, 10(2), 92-114.

Sakurai, A., Bisri, M. B. F., Oda, T., Oktari, R. S., \& Murayama, Y. (2017). Assessing school disaster preparedness by applying a comprehensive school safety framework: A case of elementary schools in Banda Aceh City. IOP Conference Series: Earth and Environmental Science, 56(1). https://doi.org/10.1088/1742-6596/755/1/011001

Shaw, R., Takeuchi, Y., \& Rouhban, B. (2009). Education, capacity building and public awareness for disaster reduction. Landslides-Disaster Risk Reduction, 499-515. https://doi.org/10.1007/978-3-540-69970-5_26

Sofyan, N., Buaja, T., \& Rahman, O. R. (2018). The implementation of role play method in improving students' speaking skill: A classroom action research at grade ix students of smp muhammadiyah 1 ternate. International Journal of Scientific and Technology Research, 7(12), 267-269.

Suharini, E., Meliana, D., Sanjoto, T., \& Kurniawan, E. (2020). The Strategy of disaster mitigation literacy through problem-based learning (PBL) in the school prone to tidal 
floods. 1st International Conference on Environment and Sustainability Issues. Semarang: Universitas Negeri Semarang.

Suharini, E., Setyowati, D. L., \& Kurniawan, E. (2017). Pembelajaran kebencanaan bagi masyarakat di daerah rawan bencana banjir DAS Beringin Kota Semarang. Forum Ilmu Sosial, 42(2), 184-195.

Susilowardhani, A. (2014). The potential of strategic environmental assessment to address the challenges of climate change to reduce the risks of disasters: a case study from Semarang, Indonesia. Procedia-Social and Behavioral Sciences, 135, 3-9. h

Thayaparan, M., Malalgoda, C., Keraminiyage, K., \& Amaratunga, D. (2014). Disaster management education through higher education - industry collaboration in the built environment. Procedia Economics and Finance, 18(9), 651-658.

Tjahjono, H., Suripin, \& Kismartini. (2019). Spatial analysis of field vulnerability concerning landslide in Southern Semarang Environment. IOP Conference Series: Earth and Environmental Science, 243(1).

Tjahjono, Heri, Suripin, \& Kismartini. (2018). Strategies for determining priority area for mitigation of landslide disaster in Semarang City. Advances in Social Science, Education and Humanities Research (ASSEHR), 313, 301-305.

Wijaya, A. K., Rahmat, R., \& Kokom, K. (2018). Reflective experiences of students to the integration of role playing model with multimedia in citizenship education. Advances in Social Science, Education and Humanities Research, 251(ACEC), 418-421.

Yulianto, T., Suripin, S., \& Purnaweni, H. (2019). Zoning landslide vulnerable area according to geological structure, slopes, and landuse parameters in trangkil sukorejo gunungpati semarang city's residental area. Journal of Physics: Conference Series, 1217(012029).

Zamboanga, B. L., Ham, L. S., Tomaso, C. C., Audley, S., \& Pole, N. (2016). “Try walking in our shoes": teaching acculturation and related cultural adjustment processes through role-play. Teaching of Psychology, 43(3), 243-249.

Zukmadini, A. Y., Kasrina, K., Jumiarni, D., \& Rochman, S. (2020). Pocketbook based on local wisdom and its effectivity in improving students' knowledge on the utilization of traditional medicine plants. Biosfer, 13(1), 59-74.

\section{Biographical Statements}

Erni SUHARINI is an Associate Professor in the Department of Geography, Faculty of Social Sciences, Universitas Negeri Semarang, and the Chair of the Geography Postgraduate Program at the Universitas negeri Semarang. She got her doctoral degree in November 2015. Her main focuses are geographical education and social sciences education curriculum development, teacher education, textbook development, environmental education, disaster mitigation, disaster education, geomorphology and soil geography.

Moh. Nasrul BAHARSYAH is a Geography Teacher in Madrasah Aliyah (Islamic Senior High School) Riyadlotut Thalabah Sedan, Sedan District, Rembang Regency, Central Java Province, Indonesia. He completed his undergraduate degree at the Geography Education Program, Department of Geography, Faculty of Social Sciences, Universitas Negeri Semarang in 2019. After that, he started to work as a geography teacher in Madrasah Aliyah (Islamic Senior High School) Riyadlotut Thalabah Sedan. His main focus is in textbook development, environmental education, disaster mitigation, disaster education, geomorphology and soil geography. 